\title{
Ceramic Clay-Arc-Decor: A New Technology for Interior and Exterior Column Designs
}

\author{
Adeoti Adebowale Abduljaleel \\ Department of Fine and Applied Arts, Federal Capital Terittory College of Education, Zuba Abuja, Nigeria \\ Email address: \\ geliloe3@gmail.com \\ To cite this article: \\ Adeoti Adebowale Abduljaleel. Ceramic Clay-Arc-Decor: A New Technology for Interior and Exterior Column Designs. Landscape \\ Architecture and Regional Planning. Vol. 6, No. 1, 2021, pp. 1-7. doi: 10.11648/j.larp.20210601.11
}

Received: September 2, 2020; Accepted: September 27, 2020; Published: March 26, 2021

\begin{abstract}
Interior and exterior designs stem from the art. Nevertheless, such design is being conceptualized as architectural design. Various materials have been supportive to climax a piece of architecture in which clay is one of them. Its versatility had evolved a new three dimensionality decor in pedagogy of ceramics in this study. The research is advancement in the art of ceramics technology where the use of clay is made possible in the production of 3-dimensional 'art-decor' installed as coverings on building surfaces such as: pillars, wall arc, and window frames. Ceramic clay-arc-décor aims to impart hands-on experience to the teaching methodology of ceramics which is essential to the minimum standard in teacher education. The research employs practical application of tools and materials to fabricate; manipulate and construct finished product. The end product is fired in terra-cotta. The study took place in the Department of Fine and Applied Arts, FCT College of Education, Zuba-Abuja in conjunction with the Ushafa Pottery Centre, Ushafa Bwari Area Council FCT Abuja. It was discovered among many recommendations that the use of clay on architectural building will reduce the burden placed on the use of cement hence improve local content consequence upon improvement of Gross domestic product.
\end{abstract}

Keywords: Architecture, Clay-Arc Decor, Terra-cotta, Column Design, Interior and Exterior Design

\section{Introduction}

Ceramics education is an integral part of visual arts curriculum in the higher institution of learning in Nigeria. It is fashioned toward promotion of aesthetics production and appreciation, technical skill and conceptual approaches. It is pertinent to mention that creative thinking toward making ceramic is tied around pottery as a craft in primary and secondary school education as supported by [21] and this is developed to a full curriculum as offshoot of visual arts in the tertiary institutions. It is from this stage that real professional skill acquisition begins and emphasis is mostly on craftsmanship technology rather than science and chemical composition of ceramics, owing to the fact that curriculum planning and requirement does not support science based subjects as prerequisite to study ceramic art in the higher institution. On this premise the study shall limit its discussion to ceramics as art rather than science.

The significance of ceramics has been exhaustively dealt with by [12] among which is addressing various households, environmental and industrial needs. Apart from ceramic table and sanitary wares which includes cups, plates, pots, vases and baths among others, Brick is used for homes and commercial buildings because of its strength, durability and beauty $[2,17,18]$. Much of the construction industry depends on the use of ceramic materials. This includes brick, cement, tile, and glass. Cement is used to make concrete which in turn is used for roadways, dams, buildings and bridges, uses of glass in the construction industry include various types of window, glass block and fibres for use in insulation of ceiling panels and roofing tiles. Tile is used in applications such as flooring, walls, countertops, and fireplaces. Tile is also a very durable and hygienic construction product that adds beauty to any application. The electronic industry would not exist without ceramics as ceramics can be excellent insulators, semiconductors, superconductors and magnets. The strength and durability of clay in building has also been re-echoed by [7].

Ceramics in Colleges of Education has remained unchanged in recent times. It is often focused on 
conventional and traditional technique and process, seemingly graduating crops of students who cannot compete with the dynamics of society. There is a need to extricate and reconstruct conventional practices from the present position. A change in methodology is proposed-moving from traditional ceramics instruction to instruction that meets the demands of education in a postmodern world. The study opined that to meet the needs of today's student, ceramics in schools should include many things beyond the conventional focus of process and pointless object-making.

A pedagogy change advocated for in this research is the use of clay in ceramic for the production of Clay-Arc-Décor as a column design for interior and exterior design, a new dimension and innovative idea in architectural building where the use of clay which is fired and installed on the pillars as a substitute for concrete.

\section{Statement of Problem}

The art of building has evolved new technologies but is still expected to embrace aesthetic preference from local content. Most preferably every houses including interior and exterior adornment should be rendered in clay as a symbol of cultural dignity and local content patronage. After all, in the olden days, our buildings were in clay and thatched roofs, yet people survived and also achieved social nobility.

Nowadays, architecture is trendy and fashionable with many foreign industrialized raw materials and accessories. For instance, the use of cement, plaster of paris, plastics, glass and polystyrene to mention but a few in building a house is on the increase especially the use of concrete column design (figure 1). Unfortunately, these materials are imported at the expense of local productivity and heighten tension on foreign exchange.

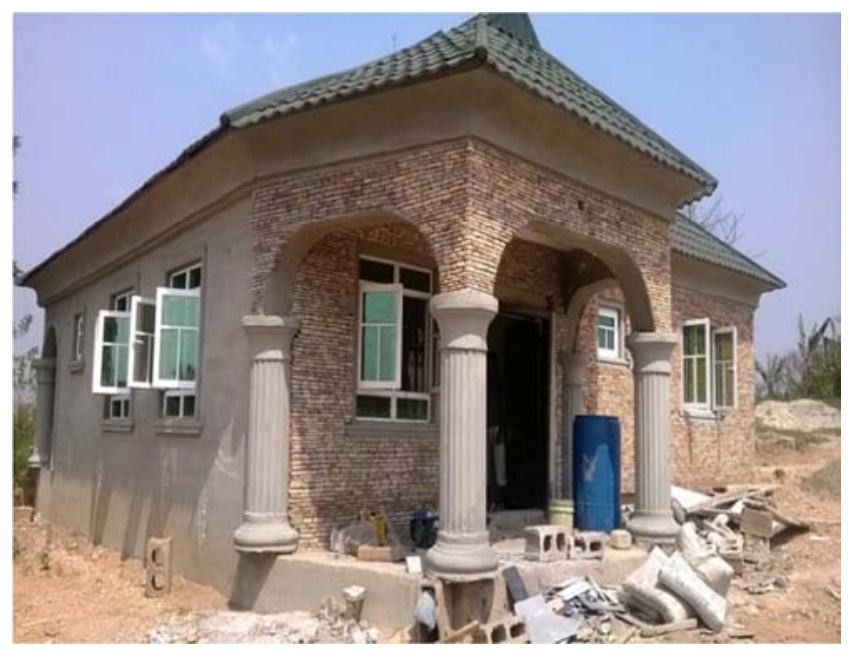

Figure 1. Concrete column designs (Adebowale, 2020).

The paradigm shift advocated for, and proposed to realize in this study is to advance the use of clay which is less expensive, strong, aesthetic and durable to achieving a trendy architectural buildings. The minimum cost of producing cement cast column design for instance is 20,000.00 for a pillar of $7 \mathrm{ft}$ tall usually on bungalow with diameter between 12 inches and 14 inches. For a duplex story building, it cost between $30,000.00$ to $35,000.00$, whereas about $10 \%$ reduction can produce clay arc-decor. It is unfortunate that foreign items have subsumed local product and for any nation to compete favourably economically, the need to jerk up national domestic product (GDP) is imperative. At least if our housing structure cannot be $100 \%$ clay, we need to look at reduction in foreign materials.

\section{Justification of the Study}

The potential of educating through ceramics education is in no doubt need to be more articulated in the current NCE curriculum accordingly, considering its interdisciplinary approach to other area of study especially in architectural design. Ceramics education should be accorded well deserving place within art education through new approach and technique of teaching that is in tandem with the current trend of modernization. Hence this study will be justified as follows:

i. Building students' capacity through new methodology in order to cope with the dynamics of labour market.

ii. A source of income to the College. This is possible when entrepreneurial venture is explored in this respect.

iii. More jobs in the real estate including clay arc-decor to feed Gross Domestic Product (GDP) which implies viability of this sector by so doing unemployment would have been reduced.

iv. Local content utilization is a national concern hence, nature given material such as clay is beneficial and consequent reducing importation of building materials.

v. Awareness of aesthetic value of interior design is not limited only to glass, iron and plastic; instead clay arcdecor will also have a place.

vi. A good alternative to cement and other materials for column design.

\section{Objectives of the Study}

i. To use clay for the production of column arc-decor as an interior/exterior design of buildings.

ii. To locate abundance available clay as a source of income for the teeming population.

iii. To increase awareness for local content appreciation.

iv. To expose visual arts students to a diverse and new method of ceramics/pottery technology.

\section{Research Questions}

i. How to use clay for the production of column arc-decor as an interior/exterior design of buildings.

ii. Where to locate abundance available clay as a source of income for the teeming population.

iii. How to increase awareness for local content 
appreciation.

iv. How to expose visual arts students to a diverse and new method of ceramics/pottery technology.

\section{Literature Review}

Clay has been responsible for the production of utilitarian wares that served mainly for domestic use. In such instances, clay is fired to a certain temperature for it to be hard enough as pot and vases to contain water and edibles. This fired clay was to be referred to as pottery/ceramics as supported by Peterson [13] having asserted that ceramics is non-metallic, inorganic materials that lend themselves to permanent hardening by high temperatures. As civilization evolved, burnt clay were later used for building purposes.

The use of clay to produce bricks and household objects and ceramics producing range from an increasing array of industrial products such as tiles, ceilings, computer chips, blast furnace linings, and electrical insulator, and lavatory as well as bathroom fixtures has been significantly dealt with by [2]. For instance clay pots are excellent for baking or serving hot food, even though [13] warned that fired clay cracks with thermal shock. Earthen ware bodies take temperature changes best because heat passes through a porous clay body.

[4], while commenting on the versatile nature of clay material and submitted that ability of clay to capture not only the human form but also the human experience undoubtedly came quickly after the manipulative quality of the material. Furthermore they added that clay in its earliest manufacture was used in modeling figurines for magical or religious purposes long before it was used to make vessels.

Clay soil can feel like a curse to gardeners and can be difficult to plant but it is excellent for potters when it is compacted, it is nearly impossible to break up using only physical strength [15].

Clay must be fired to achieve harden status and usually in ceramic firing 'Cone' is used to rate and determine level of firing meaning that you can fire that clay using a kiln at any temperature up to that cone. The closer you get to the maximum rated cone, the stronger and denser your clay will be. You cannot fire clay higher than its maximum rated Cone, or it will melt [14].

Building technology is "the art or business of assembling materials into a structure" and "practical application of knowledge especially in a particular area; a manner of accomplishing a task especially using technical processes, methods, or knowledge. Building technology encompasses everything from the ground, building, finishing and maintenance of all sorts of buildings [20].

A building is not made up of bits and pieces erected next to each other-rather, it is composed of interrelated systems and assemblies working together to contribute to its proper functioning. If these components are not carefully selected, specified, and detailed (with the designer taking into account their effects on all the other parts of the building), the completed building may not be able to protect its occupants from drafts, moisture intrusion, mold, condensation, cold, outside noise, or excessive heat [17].

[23], submitted that clay is earthy mixtures created by erosion when moist, they can take on any shape, and when fired, they become extremely durable and permanent. Clay becomes terra cotta as opined by [8] while containing about 9 percent of iron oxide which produces the characteristic red-brown fired colour. It is not strange nowadays that clay is combined with other materials to build a house. For instance, rammed earth is made of a mix of clay-rich soil, water and a natural stabilizer such as animal urine, animal blood, plant fibers or bitumen. It is then compacted inside temporary formworks that are removed after the mix has dried and hardened. The resulting structure can withstand compressive forces of up to 2.5 megapascals (around 10\% of the average compressive strength of modern bricks) [7].

\section{Research Methodology}

This study adopted practical application of tools and materials to demonstrate process of making clay arc-decor.

\subsection{Sampling and Sampling Procedure}

Pilot study/Production: Column designs are made in many sites where buildings are constructed in Abuja but the research settled for Tungamaje Community Gwagwalada Area Council of FCT Abuja for its pilot study while FCT College of Education Zuba, Abuja and Ushafa Pottery Center Ushafa Community in Bwari Area Council of FCT served as the production site.

Method of data Collection: The study employed interview technique to obtain information on the mode of casting concrete columns; certainly this gave a guide and helps to facilitate the research. Other ways of data collection includes; participant observation, focus group discussion, and secondary sources (book, journal, monograph and internet provision).

\subsection{Method of Data Analysis}

Tools and Materials for Production: Clay, Kiln, Kaolin, Gas, Cone, Plastic bowl, Mesh screen, Plastic drum, Wood, Shovel, Hand trowel, Clay sampler, Shovel, Trowel, Plastic drum, Cartridge paper, Rotering pen, Acrylic paint, Brushes, Sand and Cement, Grog, Water, Plaster of paris (POP), Modeling spatula, Grinding machine, Texture sheets, Modeling stand, Wire-end tool, Hardwood tool, Filing machine, Sand paper, Nails, Kiln, Metal ladder and Mallet as well as Pestle and Mortar.

\subsection{Analysis/Result Presentation}

Ideation: There are different types of column designs conventionally, but generally it has two forms namely flat and round shape. The drawings of different designs were made for a possible consideration of better option. However, interest of this study lies in the round shape which was finally considered for installation (figure 2). 


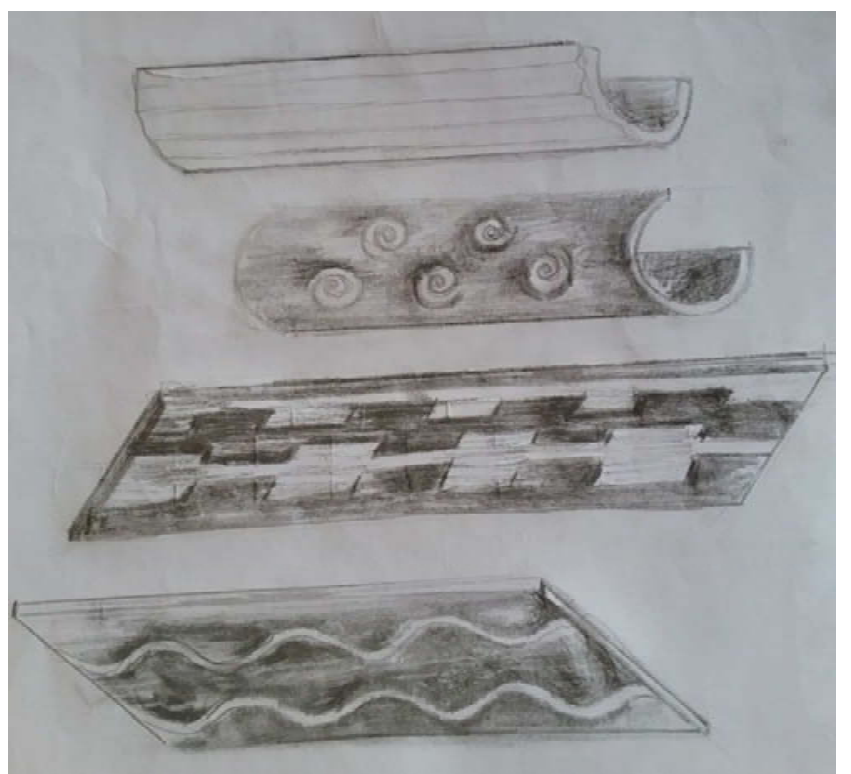

Figure 2. Sketches (Adebowale, 2020).

Site identification: The researcher visited the clay site to collect relevant clay materials around Giri junction, Gwagwalada Area Council FCT Abuja which is noted for abundance deposit through a research informant to negotiate clay site with the district head and chiefs for hitch free clay collection (figure 3). The effectiveness of the clay is ascertained by its strength being clay which has been used by the students and lecturers in the department of fine and applied arts of the FCT College of Education Zuba Abuja for over a decade.

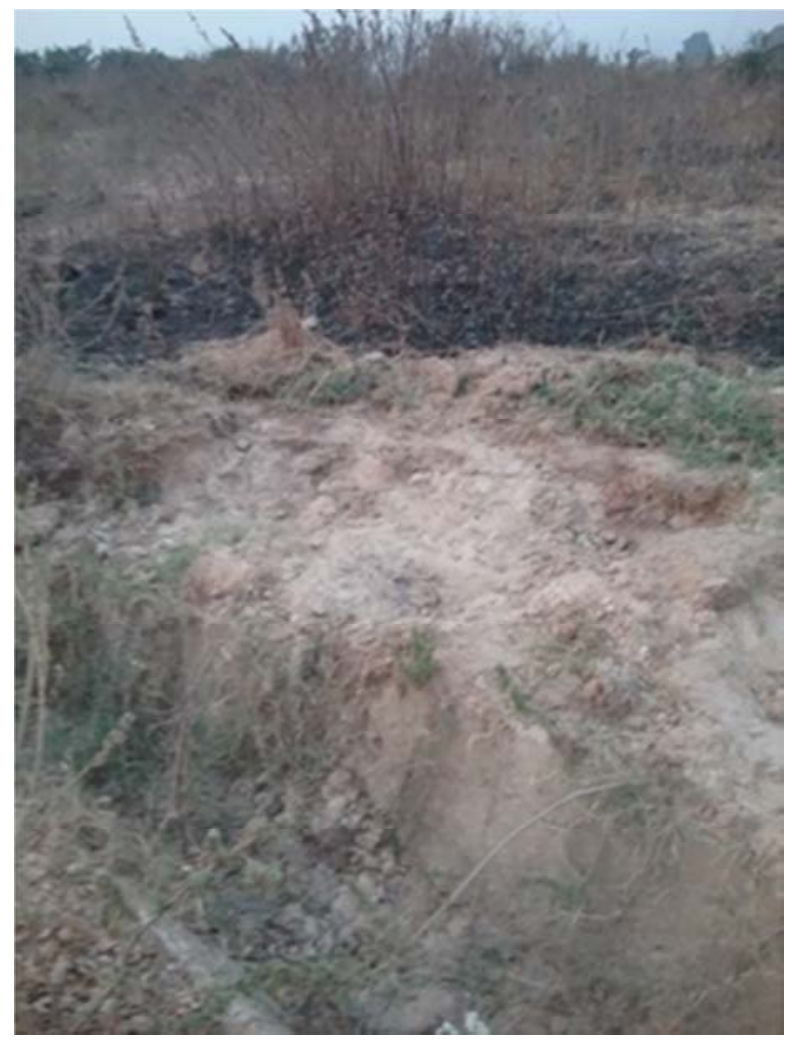

Figure 3. Clay deposit at Giri (Adebowale, 2020).
Clay collection and preparation: This involved digging of clay from the site. Clay preparation was done through the following steps; soaking, pounding and kneading (figure 4).
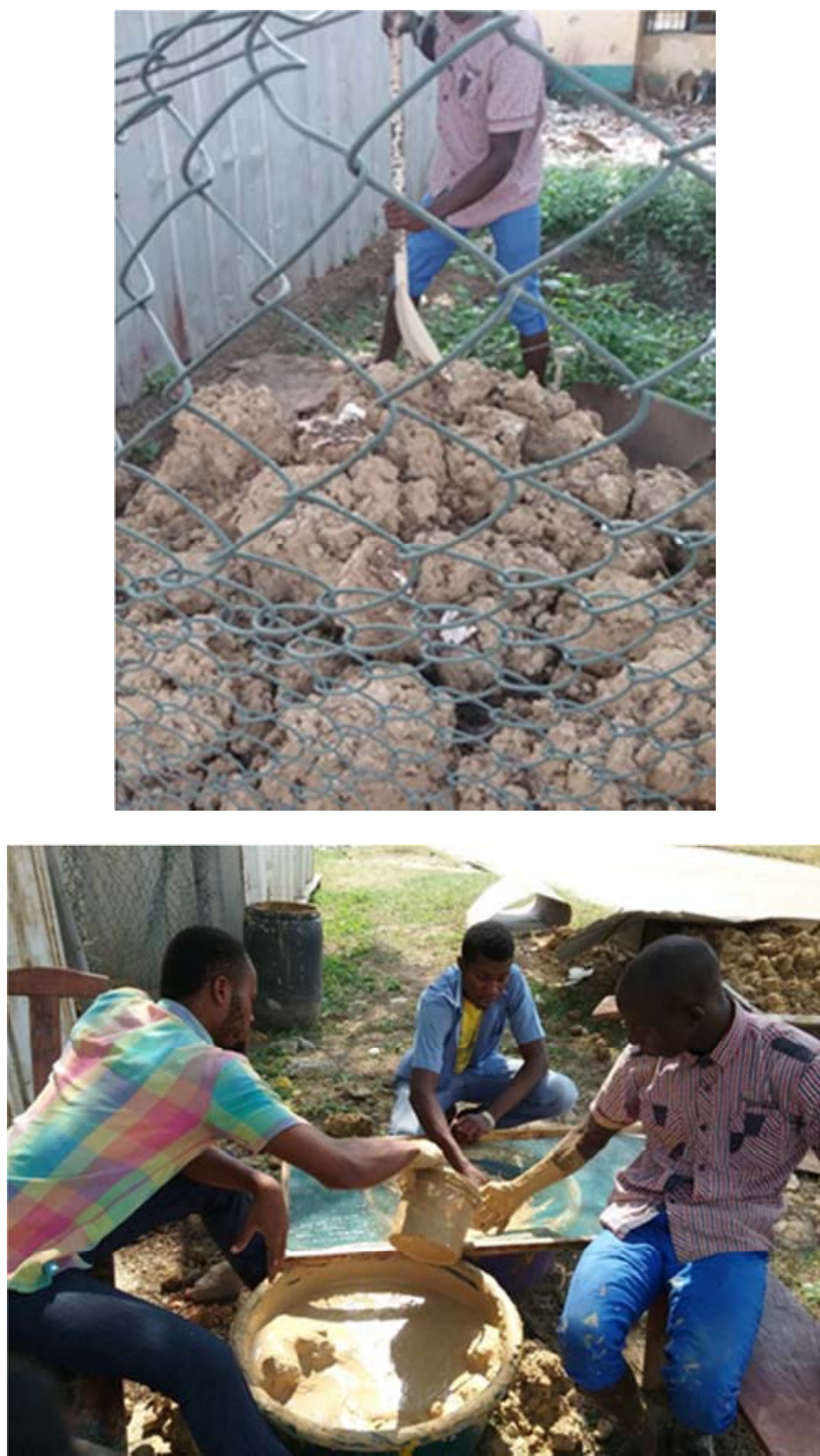

Figure 4. Clay collection and preparation deposit (Adebowale, 2020).

The clay was collected from the site, dried at $90^{\circ} \mathrm{C}$ for 24 hours, ground by using pestle and mortar into powder to reduce foreign properties (impurities). The clay was soaked inside a plastic drum for another 24 hours and sieved through clothing (synthetic fiber made) mesh to remove lumps by thorough stirring, after which fine slip is settled at the bottom part of another plastic container. Subsequently, the slip is poured inside a wide spread cotton on a flat ground in the sun to allows for evaporation consequent upon solid balls of clay. The clay is wedged by removing air bubbles, cutting the clay in to dough, beating and mixing with hands to achieved balls of clay.

Modeling: Additive and subtractive method of modeling was employed to build round and flat forms of clay arc-décor prorotype, but round forms were later used for final mould making (figure 5). 


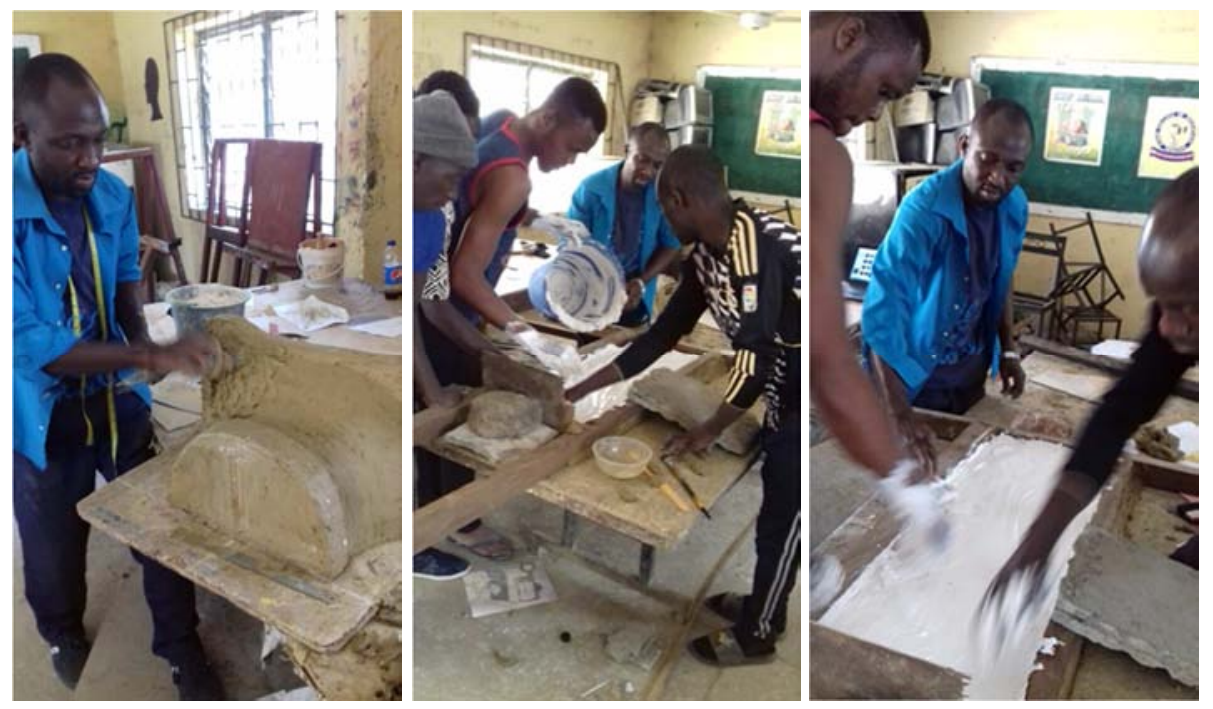

Figure 5. Modeling, mould making and casting (Adebowale, 2020).

Balls of clay were fetched to form a solid mass and hand building was done to shape up the pillar in half diameter. The shape was creatively sculpted out of the mass clay using spatula set. In order to achieve a perfect cylindrical form, plywood was cut in the same diameter form of the column and used to straightening the shape. The neck and bottom part of the column designs were made out of four slaps and joined in layers to the main body to form concentrically ring.

Making of Mould: A single mould was made out of column design since there was no under curves or complex depression on the work. The column design was rubbed with oil lubricant ready for mould casting. Plywood of the same measurement with the work was used to build a rectangular house round the work on the table and all possible openings beside the house were blocked with clay, leaving out the surface opened. Some handful quantities of plaster of paris were poured inside a bucket and mixed with water to a thickly pulp stage for about two minutes. The POP mixture was poured inside the mould house ensuring every part was covered by the slur. Subsequently, second layer was poured to fill inside the mould cast and left to dry for about 30 minutes. Later the mould was removed and left to dry hard (figure 5).

Casting: Some quantities of kaolin and grog were collected, ground to fine powder inside grinding machine. These were fetched, mixed and kneaded with balls of clay until a desire amount required was obtained. The clay was later stored inside a plastic container and covered with polythene nylon and sack under a cool temperature to prevent clay from drying. Balls of clay were collected and spread on the table to make a long slab of 1 inch $5 \mathrm{~cm}$ thickness, wide enough to cover the diameter shape of the mould, while the mould was rubbed with repellant ointment (motor engine oil). The slab of clay was later solidcast inside the mould, following its shape gradually until the whole mould is covered. Some parts of edges of the cast protruded were later trimmed to be on the same level with the edge of mould. Shortly, the cast is removed and the process continues until four pieces were achieved (figure 5).
Drying: The cast was left to dry in a low humid temperature condition under a roofing structure for period of five days to achieve leather hard.

Firing: Every clay piece assumes ceramics not until it is fired. The Giri clay used in this research takes minimum firing of $900^{\circ} \mathrm{C}$ to maximum of $1200^{\circ} \mathrm{C}$. Clay obtains its strength through firing and this is done by open or kiln firing. The research made use of gas kiln firing which is not only precise but also fastens up the process. This study found suitable the use of available kiln in one of production sites (Ushafa Pottery Center). The works were arranged horizontally in the kiln and fired at $900^{\circ} \mathrm{C}$ bisque stage. At this stage all clay body water had been driven out. The firing continued at $1200^{\circ} \mathrm{C}$ to achieve the terracotta surface and the thickness was reduced to 1 inch $2 \mathrm{~cm}$.

Installation: After firing, the work was installed with the aid of plaster sand and cement. The mixture was done to a thickly pulp and applied indiscriminately on the inside of clay arc décor and subsequently installed on a building pillar (figure 6).
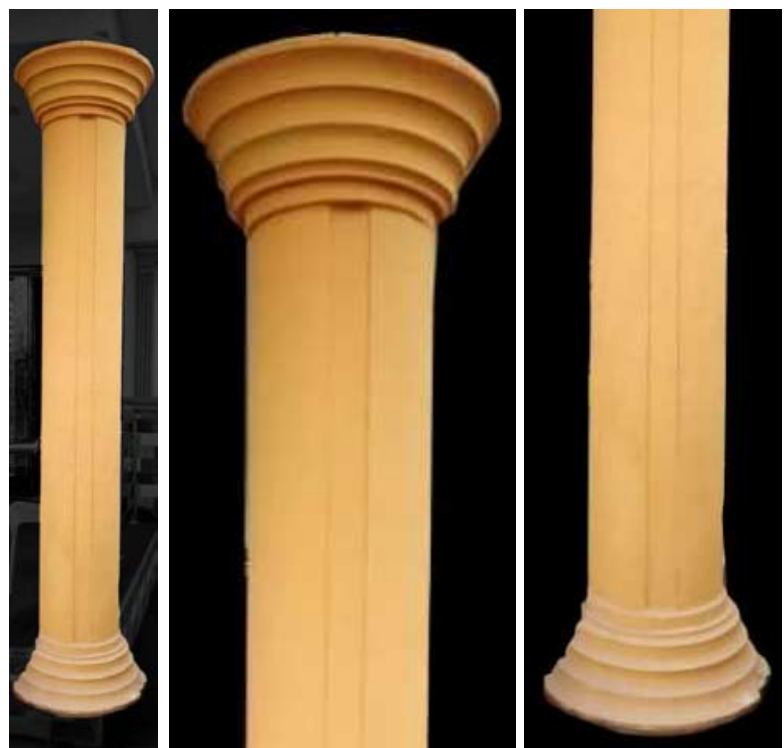

Figure 6. Finished terracotta clay arc décor (Adebowale, 2020). 
Dimension: The height is measured in 5 feet by 1 feet diameter

\section{Discussions}

The use of clay to achieve this research stemmed from long immemorial practice. Particularly the use of clay to build traditional houses has been accorded a high value content which sheltered people for many centuries as it can be seen in Nigeria. Even in the contemporary times, ceramic materials are extensively used for impact systems as remarked by Shchurova [16]. This assertion covers objective 1, also [24] attested to this fact while American Ceramic Society crowned it by submitting that ceramic materials in the form of clay figurines and pots were the first man-made materials over 10,000 years ago, and maybe even as long as 25,000 years ago.

There are different kinds of clay to make ceramics products, the research as earlier stated settled for Giri clay which has been used in the department of Fine and Applied Arts FCT College of Education Zuba Abuja over the years. The preparation follows the conventional way as $[3,1]$ stated in their work from digging, collection and final readiness to use. Various chemical compositions have been identified to make a good, pliable and plasticity, the Giri clay is plastic clay needless to mention that [1] affirmed that moisture content of the clay mixture may also be adjusted to suit a particular quality that informed the mixing of kaolin and grog to clay in this research. The location of Giri clay used in this research addressed objective 2 and 3 because the clay deposit is quite abundance for commercial purpose as well as projecting awareness of local content.

Modeling as a method of making clay arc décor is a traditional approach of hand building clay even though modern modeling (blank pressing machinery and grouting molding) mentioned by [24] can be adopted for mass production, in contrary he said more than 50 years ago, porcelain, which was produced by pressing machines and injection molding and was liked by the public, has gradually been abandoned by the public. The manual process has become the main artistic form of modern porcelain modeling. The research applied additive and subtractive method of sculpture to build the round form of column design. This can be liken to sculptural ceramics approach as supported by [9]. [9] wrote that mould making is strictly a means to a desired end. In this research the prototype mould was cast with POP as supported by [10]. The process of mixing POP in this work was similar to [11]'s work who explained that plaster mould making process probably the most popular way to make ceramics. Most famous way of producing several copies of ceramics is through slip casting. This research applied solid casting which is not popular due to the nature of the work. This approach has also been found useful in the work of [2] where a solid cast was used to achieve interlocking bricks.

There are problems usually associated with firing clay especially when the works are not of the same uniform thickness. In this research the prototype work maintained linch $5 \mathrm{~cm}$ thickness before drying and firing whereas it dropped later to 1 inch $2 \mathrm{~cm}$ due to shrinkage. This assertion was upheld by [5] where it was stated that all ceramic products also shrink when fired. In the view of [22] when pottery is drying on the shelf, the evaporating water will cause the object to shrink in size. The leather hard stage simply means that the water has evaporated from between the clay particles and the remaining clay particles are in contact. Shrinking and drying go hand in hand and how fast a clay object dries and how much the clay will shrink will affect how the objects survives in the kiln. The fact that this research was solid cast helps in drying and firing consequent upon crack free product.

Student's participation in the production process is a fit in the attempt to diversified pedagogical approach to teaching new skill and knowledge as objective 4 was realized in this direction. The teaching of new approach to ceramics has been advocated for by [21] when he presented public ceramic art education also for non-art students.

\section{Recommendations}

i. The clay site is located at the remote part of the community which development may not catch up with in the nearest future, hence the government need to safeguard the location from encroachment of human activity so as to preserve the clay site.

ii. Government should sustain and improve financial assistance offering to researcher as a motivation to keep them in the spirit of new discovery.

iii. There should be a nexus between industry and the academia in order to muster result of research for possible mass production so as to serve societal need.

iv. The concept of town and gown should be encouraged in the institution of learning whereby industrial professionals can be invited to collaborate to give hands-off experience to the students.

\section{Conclusion}

Formal ceramics art education is becoming a fundamental requirement for professional practice in ceramics in Nigeria. Considering the ample resources available for ceramic practices in the country with a teeming population of over 140 million people, there is a promising future for the art, in spite of the effects of globalization and inter-cultural infiltrations. Despite the existing raw material potential, ceramic resources are still underutilized, while the ceramic art programme still cannot produce individuals who can function productively in a highly competitive ceramics market economy.

The use of clay in ceramics education is well known to have played very impressive roles in modern architecture. Looking beyond technique of producing utilitarian object in ceramics, it is significant to embrace new methodology that can help students function effectively in the society after the completion of their NCE programme. Apart from being a 
trained teacher, their ceramics skills can be directed at handling various architectural interior and exterior decorations.

Considering the imperativeness of architectural design in space, building and environmental organization and management, the use of clay as a varied medium to produce column design is to add to aesthetic forms of building, create employment, minimize the possible dependence on foreign materials and create sustainable environmental impact.

\section{Acknowledgements}

The author gratefully acknowledges the financial support given by the Tertiary Education Trust Fund (Tetfund) towards this research.

\section{References}

[1] Aboagye, D. (2015). Multiplicity in Struggle: Ceramic Sculptures. A Master Thesis, Faculty of Art, College of Art and Built Environment Kwame Nkrumah University of Science and Technology.

[2] Adeoti, A., Ajileye, M., Odunola, Bello., Saadu, I., Victor, O and Emmanuel, A., (2011). Interlocking Bricks made from Clay as a Dynamic Alternative for Land Scape Design. International Journal of Sustainable Development, 4 (9).

[3] Alexis, C. (2016) 5 Ceramic Techniques You Need to Know. Retrieved February 20, 2020 from https://www.google.com/amp/s/www.artsy.net/article/artsyeditorial-5-ceramic-techniques-you-need-to-know/amp

[4] Arleo, A., Boger, c., Burns, M., Gonzalez, A., Jeck, D., Novak, J., Smith, N., Takamori, A and Walsh, M. (2005). The Figure in Clay: Contemporary Sculpting Techniques by Masters Artists. New York: Lark Books.

[5] BNP Media. (2020). Factors to Consider in Ceramic Drying and Firing. Retrieved February 6, 2020 from https://www.industrialheating.com/articles/95370-factors-toconsider-in-ceramic-drying-and-firing.

[6] Ciancio, D. (2015). Cheap, tough and green: why aren't more buildings made of rammed earth? Retrieved August 4, 2020 from

https://www.google.com/amp/s/theconversation.com/amp/che ap-tough-and-green-why-arent-more-buildings-made-oframmed-earth-38040

[7] Constro, F. (2020). Use of different types of clay in construction. Retrieved September 24, 2020 from https://www.google.com/amp/s/www.traditionalbuilding.com/. amp/opinions/a-look-at-clay

[8] Fraser, H. (1998). Glazes for the Craft Potter. London. A\&C Black (Publisher) Ltd.

[9] Gilliatt, A. (2020). How to Make a Model and a Mold for Slip Casting. Retrieved from February 6, 2020 from https://ceramicartsnetwork.org/freebies/free-guides/ceramicmold-making-techniques/
[10] Guy Michael, D. (2020). Plaster Mixing 101: How to Mix Plaster for Ceramic Moulds. Retrieved from February 7, 2020 from https://ceramicartsnetwork.org/daily/pottery-makingtechniques/making-ceramic-molds/how-to-mix-plaster-forceramic-molds/

[11] Jackie, H. (2020). Making Ceramic Moulds: How to Make a Plaster Mould for Slip Casting. Retrieved from February 21, 2020 from

https://thelibraryofmanufacturing.com/ceramic_mold_casting. html

[12] Okonkwo, I. E. (201 4). Students' Perception of Ceramics Education in Nigeria Tertiary Institutions. An International Multidisciplinary Journal, Ethiopia, 8 (2), 217-2.

[13] Peterson, S. (1992). A Complete Potter's Hand Book: The Craft and Art of Clay. London. Laurence King Publishing.

[14] Pottery. (2017). Pottery and Sculpting Clay. Retrieved May 23, 2019 from http://www.bigceramicstore.com/clays.html big.

[15] Reference. (2017). Science of Clay. Retrieved May 19, 2019 from https://www.reference.com/science/clay-soil6be122f4b8cb12da.

[16] Shchurova, E. I. (2016). Modeling of the Ceramics Structure for the Finite Element Analysis. Proceedings of International Conference on Industrial Engineering (ICIE), 150: 179-184.

[17] Sullivan, L. (2014). what-is-building-technology. Retrieved July 16, 2019 from https://www.constructionspecifier.com/what-is-buildingtechnology/

[18] Webb, P. (2020). From Dust We Come: A Look at Clay. Retrieved September 24, 2020 from https://www.google.com/amp/s/www.traditionalbuilding.com/. amp/opinions/a-look-at-clay

[19] Wienerberger, W. (2020). Clay building materials Advantages. Retrieved September 24, 2020 from https://wienerberger-world.com/expertise/clay-buildingmaterials-advantages/

[20] Word Skills International. (2017). Building Technology. Retrieved May 20, 2019 from https://www.worldskills.org.

[21] Xiangcui, H. (2018). Research and Practice of Public Ceramics Teaching Platform-Study on the sharing of Primary and Secondary Schools and University Platforms. Advances in Economics, Business and Management Research, volume 75,8 th International Conference on Education and Management (ICEM 2018).

[22] Yadawei Studio Staff. (2016). The essential drying process for ceramics. Retrieved May 20, 2019 from https://www.google.com/amp/s/www.yadawei.net/singlepost/2016/08/21/The-essential-drying-process-for-ceramics

[23] Zakin, R. (1990). Ceramics: Mastering the Craft. London. A\&C Black (Publisher) Ltd.

[24] Zhao Shouli, L. (2019). Analysis of the Relationship between Modelling and Decoration in Ceramic Design. Advances in Economics, Business and Management Research, volume 109. 